\title{
ADHERENCE TO TREATMENT REGIMENS IN PATIENTS WITH CARDIOVASCULAR DISEASES
}

\section{PRZESTRZEGANIE ZALECEŃ LEKARSKICH PRZEZ PACJENTÓW Z CHOROBAMI UKŁADU KRĄŻENIA}

\author{
Lucia Dimunová $^{1(\mathrm{~A}, \mathrm{D}, \mathrm{E}, \mathrm{F})}$, Jana Michalková ${ }^{1(\mathrm{~A}, \mathrm{E}, \mathrm{F})}$, Mária Zamboriová $^{1(\mathrm{~A}, \mathrm{E}, \mathrm{F})}$, \\ Jana Bučková ${ }^{2(A, B, E)}$, Iveta Rajničová Nagyová ${ }^{2(A, C, D, E, G)}$ \\ ${ }^{1}$ Department of Nursing, Faculty of Medicine, Pavol Jozef Šafárik University in Košice, Slovakia \\ ${ }^{2}$ Department of Social and Behavioral Medicine, Faculty of Medicine, Pavol Jozef Šafárik University in Košice, Slovakia
}

Authors' contribution Wkład autorów: A. Study design/planning zaplanowanie badań B. Data collection/entry zebranie danych C. Data analysis/statistics dane - analiza i statystyki D. Data interpretation interpretacja danych E. Preparation of manuscript przygotowanie artykułu F. Literature analysis/search wyszukiwanie i analiza literatury G. Funds collection zebranie funduszy

Tables: 1

Figures: 0

References: 29

Submitted: 2021 Aug 31

Accepted: 2021 Oct 18

\section{Summary}

Background. Adherence is an important parameter of any effective treatment. This study aimed to evaluate adherence/non-adherence in patients with cardiovascular diseases and to determine whether sociodemographic characteristics affected treatment adherence.

Material and methods. The study sample consisted of 878 patients with coronary heart disease. A non-standardized questionnaire was used to obtain the data. The data was statistically evaluated using SPSS.25.0.

Results. Adherence was demonstrated in 501 (57.4\%) patients. A statistically significant relationship was confirmed between adherence to treatment and gender $(p=0.000)$ and employment $(\mathrm{p}=0.001)$. Patients $\geq 58$ years of age with basic education and who earn an average income have a higher adherence rate to treatment.

Conclusions. Knowledge of how a patient's sociodemographic characteristics affect adherence can help healthcare professionals to effectively educate patients and improve their quality of life.

Keywords: treatment adherence, cardiovascular diseases, patients

\section{Streszczenie}

Wprowadzenie. Przestrzeganie zaleceń lekarskich jest jednym z ważnych parametrów skutecznego leczenia. Celem pracy była ocena stosunku do zaleceń lekarskich (przestrzegający/ nieprzestrzegający) u pacjentów z chorobami układu krążenia oraz ustalenie czy cechy socjodemograficzne wpływają na przestrzeganie zaleceń.

Materiał i metody. W badaniu uczestniczyło 878 pacjentów z chorobą niedokrwienną serca. Do zebrania danych wykorzystano niestandaryzowany kwestionariusz. Dane poddano analizie statystycznej w programie SPSS.25.0.

Wyniki. Przestrzeganie zaleceń lekarskich zaobserwowano u 501 (57,4\%) pacjentów. Potwierdzono istotną statystycznie zależność między płcią $(p=0,000)$ oraz zatrudnieniem $(\mathrm{p}=0,001)$ a przestrzeganiem zaleceń lekarskich. Pacjenci $w$ wieku $\geq 58$ lat, $\mathrm{z}$ wykształceniem podstawowym i średnimi dochodami finansowymi, wykazują częstsze przestrzeganie zaleceń lekarskich.

Wnioski. Wiedza na temat wpływu cech socjodemograficznych pacjentów na przestrzeganie zaleceń lekarskich może pomóc pracownikom służby zdrowia w prowadzeniu skutecznej edukacji pacjentów i poprawić jakość ich życia.

Słowa kluczowe: przestrzeganie zaleceń lekarskich, choroby układu krążenia, pacjenci 


\section{Introduction}

Cardiovascular disease is a major cause of morbidity and mortality and has been increasing in recent decades representing a significant problem in health systems around the world [1]. Adherence is an important factor in successfully managing chronic diseases. Adherence is defined by the World Health Organization as the extent to which a person's behavior such as taking medication, following a diet, or executing a certain lifestyle corresponds with the recommendations of their health care provider [2]. Cardiac medication adherence is important to avoid morbidity and premature mortality in patients with cardiovascular diseases [3]. Adherence to prescription medications is necessary for one to receive the full benefits of the medication, but it is a complex and dynamic process. This is particularly challenging for patients with cardiovascular diseases who are predominantly discharged from hospitals on long-term polypharmacy [4]. Medication non-adherence occurs repeatedly in clinical practice [5] and the level of treatment adherence is still low according to ESC recommendations [6]. Adherence can be affected by various factors such as lack of patient knowledge, lack of belief in the need for medication, fear of drug side effects, insufficient care coordination, high medication costs, or forgetting to take medication [7-10]. A systemic review by Leslie et al. [11], found that adherence was associated with disease factors, therapeutic factors, health care factors, patient attitude, and social status. The consequences of nonadherence are higher treatment costs, increased rehospitalization risk [12], and decreased quality of life.

This study aimed to evaluate adherent/non-adherent behavior in patients with cardiovascular disease and to evaluate whether sociodemographic characteristics affect patient adherence to treatment.

\section{Material and methods}

The study consisted of 878 patients with coronary heart disease (CHD). Inclusion criteria included patients with a confirmed medical diagnosis of coronary heart disease, patients undergoing selective coronary angiography, and patients after coronary angiography or angioplasty. Patients with severe cerebrovascular disease, severe dementia, and severe psychiatric illness were excluded from the study.

A non-standardized questionnaire was used for data collection. The first part of the questionnaire focused on socio-demographic data (gender, age, education, employment, and financial status). These eight questions were used to assess adherent behavior to the prescribed treatment regimen: 1 . Taking prescribed medication; 2. Adherence to the recommended diet; 3. Doctor's visits due to disease during the last year; 4. Doctor's visits to prescribe medicines during the last year; 5 . Adherence to the recommended medication time; 6 . Adherence to the amount of the prescribed drug; 7. Change of used drugs due to high price; 8. Interest in symptoms which prescribed drugs should remove.

A histogram was generated based on the frequency of correct responses and the mean of correct responses $(M=5.55 ; S D \pm 1.34)$ with a minimum value of 1 and a maximum value of 8 . The research sample was divided into two groups - patients with adherent and patients with non-adherent behavior. Adherent behavior was defined as $\geq 6$ correct answers and non-adherent behavior as $<6$ correct answers. A normality test was used to verify the data set, which demonstrated a normal distribution and a relevant distribution of the selection. A value of $0.201(p=0.000)$ was obtained using the Kolmogorov-Smirnov test, and the Shapiro-Wilk test generated a value of $0.936(\mathrm{p}=0.000)$.

The research was carried out in a specialized medical facility at the East Slovak Institute of Cardiovascular Diseases, a.s. Košice (VÚSCH, a.s.). The study protocol was approved by the Ethics Committee of the Faculty of Medicine at Pavol Jozef Šafárik University in Košice (approval no. 115/2011), and all patients gave written informed consent before participating in the study.

Statistical analyses were performed using the SPSS software version 25.0 for Windows (SPSS Inc, Chicago, Illinois). The Kolmogorov-Smirnov test and Shapiro-Wilkovov test were used to verify the normal distribution of continuous variables. Results were analyzed using descriptive statistical methods, Pearson's correlation coefficient chi-square test (r), and Fisher's test (F). Statistical significance was defined as a p-value of $<0.05$.

\section{Results}

The study involved 878 patients with coronary heart disease. The mean age of patients in the study was 57.81 years ( $\mathrm{SD} \pm 7.58$ years) with a median value of 58.00 . The research sample was divided into two groups by age, patients $<58$ and $\geq 58$ based on the histogram. The age range of the research sample was 24 to 75 years. The group consisted of $60 \%$ men $(n=527)$ and $40 \%$ women $(n=351)$. Most patients reported primary education $40.9 \%$ $(n=359)$, and secondary education $36.4 \%(n=320)$. The lowest proportion was represented by patients with 
a degree from a university, $22.7 \%(n=199)$. In terms of social variables, our research focused on financial income and employment. Financial income was divided according to the subsistence minimum. It was found that the subsistence minimum included $14.4 \%$ (n=127) of respondents; $1.5-2$ times the subsistence minimum included $52.4 \%(n=460)$ of respondents, and 2.5 times the subsistence minimum included $33.2 \%$ ( $=291$ ) of respondents. Five hundred thirty-one (60.5\%) participants were employed, while 347 (39.5\%) were unemployed which included those receiving an old-age pension, disability pension, or were a student. Adherent behavior was seen in 501 (57.4\%) patients whereas non-adherent behavior occurred in 377 (42.6\%) patients. The relationships between individual variables and the patient's adherence to treatment are presented in Table 1.

Table 1. Patient adherence to treatment in relation to selected variables

\begin{tabular}{|c|c|c|c|}
\hline Variables & $\begin{array}{c}\text { Non-adherence } \\
\text { N (\%) }\end{array}$ & $\begin{array}{c}\text { Adherence } \\
\text { N (\%) }\end{array}$ & p-value \\
\hline $\begin{array}{l}\text { gender } \\
\text { male } \\
\text { female }\end{array}$ & $\begin{array}{l}253(28.8) \\
121(13.8)\end{array}$ & $\begin{array}{l}277(31.2) \\
230(26.2)\end{array}$ & $0.000^{* * *}$ \\
\hline $\begin{array}{c}\text { age } \\
\text { younger }<58 \mathrm{y} \\
\text { older } \geq 58 \mathrm{y}\end{array}$ & $\begin{array}{l}191(21.8) \\
187(21.3)\end{array}$ & $\begin{array}{l}225(25.6) \\
275(31.3)\end{array}$ & 0.105 n.s. \\
\hline $\begin{array}{l}\text { education } \\
\text { elementary } \\
\text { secondary } \\
\text { university }\end{array}$ & $\begin{array}{l}144(16.4) \\
158(18.0) \\
82(9.3)\end{array}$ & $\begin{array}{l}215(24.5) \\
162(18.5) \\
117(13.3)\end{array}$ & 0.143 n.s. \\
\hline $\begin{array}{c}\text { financial income } \\
\text { subsistence minimum } \\
\text { average income } \\
\text { above-average income }\end{array}$ & $\begin{array}{c}58(6.6) \\
203(23.1) \\
124(14.1)\end{array}$ & $\begin{array}{c}69(7.9) \\
257(29.3) \\
167(19.0)\end{array}$ & 0.789 n.s. \\
\hline $\begin{array}{c}\text { employment } \\
\text { employed } \\
\text { unemployed }\end{array}$ & $\begin{array}{l}258(29.4) \\
131(14.9)\end{array}$ & $\begin{array}{l}273(31.1) \\
216(24.6)\end{array}$ & $0.001^{* *}$ \\
\hline
\end{tabular}

A statistically significant relationship between gender, employment, and treatment adherence was confirmed in our research study. In the context of adhering to a treatment regimen, men showed higher adherence to treatment compared to women. Employed patients also were found to have a more responsible approach to treatment compared to non-employed patients. According to our findings, treatment adherence was not significantly affected by age, education, or income. Based on the relative number with respect to age, we can state that patients $\geq 58$ years are more adherent $(n=275 ; 31.3 \%)$ compared to patients younger than 58 years $(n=225 ; 25.6 \%)$. Education also does not have a significant impact on adherence to a treatment regimen. In relation to financial situation, patients with an average income appear to be the most responsible in taking care of their health.

\section{Discussion}

Adherence is a problem that exists across the spectrum of both primary and secondary prevention of chronic diseases and represents a serious problem in patients with coronary heart disease [13]. Overall, 57.4\% of patients in our cohort were adherent, which we do not consider sufficient. However, this is better than reported by Zyryanov et al. [14], where non-adherence in coronary outpatients exceeded 50\%. Inconsistent results in relation to gender and adherence have been described in the literature. In our research, men $(p=0.000)$ behaved more adherently than women, which agrees with some authors [15,16]. On the other hand, Viana et al. [17] found a lower drug adherence in men than in women with cardiovascular disease and heart failure. Assawasuwannakit et al. [18] point out that older age is associated with poorer adherence to treatment, which was not confirmed in our group of patients. However, this fact is to some extent expected due to the cognitive changes during the aging period [19], as elderly patients have a reduced ability to understand, respect, and follow the recommendations of healthcare professionals. In our research, based on relative numbers, more adherent behavior was demonstrated by elderly patients $(\geq 58)$, which as stated by Slabá et al. [19] may be related to social and family background, a higher level of physician empathy, and a mutual atmosphere of trust. Kardas et al. [20] highlights the effect of education levels and healthcare literacy in connection with treatment adherence and found worse adherence in patients with lower education. Similar findings were presented by Szlenk-Czyczerska [21] where higher levels of 
health behavior in all categories related to adherence to the treatment regimen were found in people with higher or secondary education. In regards to financial income, it is clear from our results that low-income patients are less adherent. Lee et al. [22] states that treatment adherence is employment-related, which is in line with our findings that working patients are more adherent than those who are not employed.

Domestic and foreign results confirm the need to monitor and address treatment adherence issues. From the perspective of patients, healthcare professionals, and healthcare systems, there are potentially many approaches that could help improve adherence. We agree with the authors' opinions [23-28] that one of the most effective and important ways is providing consistent patient education. Other alternatives are to use motivational interviewing [29] or a mobile phone application [5]. Achieving optimal patient treatment adherence requires an individual approach and multidisciplinary cooperation. Improving adherence is likely to benefit the patient more than introducing additional therapies.

\section{Conclusions}

It is necessary to take into account the risk factors associated with adherence in the management of cardiovascular diseases. Previous studies addressing treatment adherence have varying quality and considerable heterogeneity. Although some systematic reviews have considered several factors, many primary studies look at risk factors in isolation without considering their possible relationships. The results of our study show that the success of the treatment regimen can be significantly influenced by gender and employment. Based on relative abundance, we found that patients aged $\geq 58$ years with basic education and average financial income have higher adherence to treatment. A patient's socio-demographic characteristics can alert the physician and nurse to the possible risk of non-adherence and can direct effective communication and education from the beginning of treatment.

\section{Disclosures and acknowledgments}

The authors declare no potential conflicts of interest with respect to the research, authorship, and/or publication of this article. This work was supported by the Slovak Research and Development Agency under contract APVV-15-0719.

\section{References:}

1. Gajdošík J. [Adherence of treatment - the most important part of achieving the effect of therapy in chronic diseases]. AtheroRev. 2017; 2(1): 15-19 (in Slovak).

2. World Health Organization. Adherence to long-term therapies: evidence for action. Geneva: World Health Organization; 2003.

3. Al-Ganmi AHA, Alotaibi A, Gholizadeh L, Perry L. Medication adherence and predictive factors in patients with cardiovascular disease: a cross-sectional study. Nursing \& Health Sciences. 2020; 22: $454-463$. https://doi.org/10.1111/nhs.12681

4. Pandey A, Clarus S, Choudhry N. Extended exercise cardiac rehabilitation improve medication adherence post-mi: the extend study. Journal of the American College of Cardiology. 2018; 71(11): A1883. https://doi.org/10.1016/S0735-1097(18)32424-0

5. Park JYE, Li J, Howren A, Tsao NW, De Vera M. Mobile phone apps targeting medication adherence: quality assessment and content analysis of user reviews. JMIR Mhealth Uhealth. 2019; 7(1): e11919. https://doi.org/10.2196/11919

6. Piepoli MF, Hoes AV, Agewall S, Albus CH, Brotons C, Catapano AL, etal. European Guidelines on cardiovascular disease prevention in clinical practice: The Sixth Joint Task Force of the European Society of Cardiology and Other Societies on Cardiovascular Disease Prevention in Clinical Practice (constituted by representatives of 10 societies and by invited experts) developed with the special contribution of the European Association for Cardiovascular Prevention \& Rehabilitation (EACPR). EHJ. 2016; 37(29): 2315-2381.https://doi.org/10.1093/ eurheartj/ehw106

7. Ogungbe 0, Dennison Himmelfarb CHRD, Commodore-Mensah Y. Improving medication adherence in cardiovascular disease prevention: what's new?. J Cardiovasc Nurs. 2020; 35(1): 6-1. https://doi.org/10.1097/ JCN.0000000000000645

8. Morrison A, Stauffer ME, Kaufman AS. Defining medication adherence in individual patients. Patient Preference and Adherence. 2015; 9: 893-897. https://doi.org/10.2147/PPA.S86249 
9. BeMedicine Smart National Council on Patient Information and Education. Accelerating progress in prescription medicine adherence: the Adherence Action Agenda. A National Action Plan to Address America's "Other Drug Problem“. Rockville, MD: National Council on Patient Information and Education; 2013.

10. Brown MT, Bussell JK. Medication adherence: WHO cares?. Mayo Clin. Proc. 2011; 86(4): 304-314. https://doi.org/10.4065/mcp.2010.0575

11. Leslie KH, McCowan C, Pell JP. Adherence to cardiovascular medication: a review of systematic reviews. J Public Health. 2018; 41(1): e84-e94. https://doi.org/10.1093/pubmed/fdy088

12. Al-Ganmi AHA, Perry L, Gholizadeh L, Alotaibi AM. Cardiovascular medication adherence among patients with cardiac disease: a systematic review. J Adv Nurs. 2016; 72(12): 3001-3014. https://doi.org/10.1111/ jan.13062

13. Keenan J. Improving adherence to medication for secondary cardiovascular disease prevention. Eur J Prev Cardiol. 2017; 24(3S): 29-35. https://doi.org/10.1177/2047487317708145

14. Zyryanov SK, Fitilev SB, Vozzhaev AV, Shkrebniova II, Shindryaeva NN, Klyuev DA, et al. Medication adherence in patients with stable coronary artery disease in primary care. Research Results in Pharmacology. 2020; 6(2): 97-103. https://doi.org/10.3897/rrpharmacology.6.54130

15. Ogna VF, Burnier M. Determinants and barriers to adherence in hypertension. In: Burnier M., editor. Drug adherence in hypertension and cardiovascular protection. Cham: Springer; 2018. p. 107-122. https://doi.org/10.1007/978-3-319-76593-8

16. Mann DM, Woodard M, Muntner P, Falzon L, Kronish I. Predictors of nonadherence to statins: a systematic review and meta-analysis. Ann Pharmacother. 2010; 44(9): 1410-1421. https://doi.org/10.1345/aph.1P150

17. Viana M, Laszczynska O, Mendes S, Friões F, Lourenço P, Bettencourt P, et al. Medication adherence to specific drug classes in chronic heart failure. J Manag Care Spec Pharm. 2014; 20(10): 1018-1026. https://doi.org/10.18553/jmcp.2014.20.10.1018

18. Assawasuwannakit P, Braund R, Duffull SB. A model-based metaanalysis of the influence of factors that impact adherence to medications. J Clin Pharm Ther. 2015; 40(1): 24-31. https://doi.org/10.1111/jcpt.12219

19. Slabá Š. [Adherence to treatment from the perspective of a psychologist]. AtheroRev. 2017; 2(1): 21-24. (in Czech).

20. Kardas P, Lewek P, Matyjaszczyk M. Determinants of patient adherence: a review of systematic reviews. Frontiers in Pharmacology. 2013; 4(91): 1-16. https://doi.org/10.3389/fphar.2013.00091

21. Szlenk-Czyczerska E, Semla W, Jenczura AM. Assessment of health behaviors of patients with heart failure treated in a cardiology department. Health Prob Civil. 2021; 15(2): 79-86. https://doi.org/10.5114/ hpc.2021.104625

22. Lee GKY, Wang HHX, Liu KQL, Cheung Y, Morisky DE, Wong MCS. Determinants of medication adherence to antihypertensive medications among a Chinese population using Morisky Medication Adherence Scale. PLoS ONE. 2013; 8(4): e62775. https://doi.org/10.1371/journal.pone.0062775

23. Kristová J, Bachratá Z, Slezáková Z, Miklovičová E. Implementation of telenursing in the Slovak Republic. Pielegniarstvo XXI wieku/Nursing in the 21 st Century. 2021; 20(3): 216-220. https://doi.org/10.2478/ pielxxiw-2021-0028

24. Olišarová V, Chloubová I, Prokešová R, Šedová L, Tóthová V. Exercise in prevention of cardiovascular diseases, as seen in population aged 40+. Cent Eur J Nurs Midw. 2019; 10(1): 986-992. http://doi.org/10.15452/ CEJNM.2019.10.0005.

25. Grešš Halász B, Majerníková L, Obročníková A, Hudáková A, Vojteková M. Developing the advanced practice nursing role in Slovakia: Perception, education, and practice. J Am Assoc Nurse Pract. $2020 ; 10$. https://doi.org/10.1097/JXX.0000000000000460

26. Hulková V. [Standardization in nursing]. Martin: Osveta; 2016. p. 232 (in Slovak).

27. Červený M, Siaki LA, McGee P, Kilíková M. Perception of European nurses of culturally-appropriate health care - a cross-sectional study. Med Og Nauk Zdr. 2019; 25(1): 27-32. https://doi.org/10.26444/monz/102392

28. Sováriová Soósová M, Hrehová J. The effect of education on lifestyle changes and metabolic syndrome components. Cent Eur J Nurs Midw. 2014; 5(4): 161-168. https://doi.org/10.15452/CEJNM.2014.05.0012

29. Beltrán LFA. Effect of motivational interesting on cardiovascular patient adherence. Enfermería Global. 2019; 18(4): 472-484. https://doi.org/10.6018/eglobal.18.4.341611 